\title{
Green Credit, Financial Ecological Environment, and Investment Efficiency
}

\author{
Meng Qi 1 (D) \\ College of Marxism, Shandong University of Science and Technology, Qingdao 266590, China \\ Correspondence should be addressed to Meng Qi; qimeng@sdust.edu.cn
}

Received 12 January 2021; Revised 10 February 2021; Accepted 20 February 2021; Published 2 March 2021

Academic Editor: Lei Xie

Copyright (C) 2021 Meng Qi. This is an open access article distributed under the Creative Commons Attribution License, which permits unrestricted use, distribution, and reproduction in any medium, provided the original work is properly cited.

\begin{abstract}
This article uses the "Green Credit Guidelines" issued in 2012 as a quasi-natural experiment, using the statistics of A-share listed companies from 2008 to 2017, using the PSM-DID model to examine the effect and mechanism of green credit policies on the investment efficiency of heavily polluting companies, and taking into consideration the heterogeneous influence of the financial ecological environment on the relationship between the two. The research indicates that, after the Green Credit Guidelines were promulgated, the investment efficiency of heavy-polluting companies has been slightly improved compared with non-heavypolluting companies and that the impact is more obvious in regions with better financial ecological environment. The research conclusions confirm the beneficial effects of the Green Credit Guidelines policy on the prudent investment of companies that cause serious pollution to the environment and improve investment efficiency, a provision of empirical evidence for financial leverage to drive the green economy transformation.
\end{abstract}

\section{Introduction}

In June 2015, the Environmental Protection Department of Liaoning Province, in conjunction with financial institutions, imposed green credit restrictions on 37 companies that violated environmental laws. These companies are mainly involved in heating, chemical, financial, smelting, papermaking, electroplating, and other industries that seriously pollute the environment. The environmental protection department will follow up the supervision of these enterprises, and the restrictions can only be lifted after the rectification of their problems is in place. Contrary to the restrictions on loans in the first quarter of 2013, the Agricultural Bank of China Zhejiang Branch issued 7.2 billion yuan in loans to 47 green environmental protection projects, 3.5 billion yuan increased over the same period of the previous year; the bank's "green loan" balance reached 30.5 billion yuan. Its loans are mainly for infrastructure projects such as clean energy, sewage treatment, garbage treatment, and energy-saving services. The above two scenarios are real cases of economic transformation driven by green credit. Especially, since the promulgation of the "Green Credit
Guidelines" in 2012 (hereinafter referred to as the "Guidelines"), China's green credit scale has gradually expanded. As of the end of June 2020, China's green credit balance has exceeded 11 trillion yuan, taking a leading position in the world; China's stock of green bonds is 1.2 trillion yuan, which takes the runner-up position in the world.

From the perspective of the implementation path of green credit, on the one hand, by raising the loan threshold for heavily polluting industries, companies are forced to undergo green transformation and upgrading. On the other hand, it focuses on supporting the financing of environmental protection industry, clean energy, sewage treatment, and other livelihood projects, alleviating their financing constraints, and promoting the rapid development of green industries. The promulgation of the Green Credit Guidelines is a significant measure for financial services in the real economy, aiming to enhance the efficiency of fund spending in heavily polluting industries and environmentally friendly industries. Therefore, after the reform and exploration in recent years, what is the effect of the policy? Can the inefficient investment of heavily polluting enterprises be truly 
improved? This series of questions urgently need to be tested by theoretical research.

Looking back to existing research, green credit policies mainly play a part in the transmission of financial entities and how the effect of the policy depends on the response of microenterprises. Aizawa and Chaofei [1] and Naveiro and Aoussat [2] pointed out that the core purpose of green finance is to promote the coordinated and sustainable development of economic and ecological benefits. However, sustainable development is inseparable from the efficient investment efficiency of enterprises; information asymmetry and agency problems often make enterprise investment deviate from the optimal level, resulting in low investment efficiency of enterprises $[3,4]$. The issuance of green loans does not improve public expectations of enterprises in the green industry [5]. The promulgation of the green finance policy requires polluting companies to disclose their environmental information and reduce the information asymmetry between banks and enterprises; by adjusting financial resources, the financing costs and investment risks of polluting companies can be increased $[6,7]$. Therefore, through the promulgation of the green credit policy, the amount of financing that heavily polluting companies can obtain from financial institutions has been reduced. Enterprise management must reassess the future capital operation status, carefully select investment projects, and change the direction of investment to reduce inefficient investment and improve the investment efficiency of heavily polluting enterprises. Green credit policy can encourage enterprises to pay attention to early prevention and control measures rather than late mitigation measures [8]. In addition, the implementation effect of green credit policies between regions is closely related to the differences in the financial ecological environment. The financial ecological environment will have a certain degree of impact on corporate debt financing costs, financing structure, debt maturity, etc. [9-12]. Green credit policy is effective in suppressing the investments of energy-intensive industries. Liu et al. and Michael $[13,14]$ showed that the quality of the financial ecological environment has a certain degree of influence on the credit financing capacity and credit term structure of enterprises. Dosi [15] found that the financial ecological environment's constraints and incentives for the operation of the financial market are affected by many factors such as social economy, systems, law, people's living standards, and education which ultimately lead to different behaviors of financial entities. In summary, the impact of green credit policies on corporate investment efficiency will vary due to differences in the financial ecological environment. Therefore, under the strategic background of financial services in the real economy, how the green credit policy guides the investment behavior of companies that cause serious pollution to the environment is a practical issue that needs to be immediately handled in the theoretical and academic circles. Studying the relationship between the two has important theoretical and practical significance for improving green finance to serve the real economy and driving the green transformation of heavily polluting enterprises.
Based on this, this article selects my country's A-share listed companies from 2008 to 2017 as the research sample, distinguishing heavy-polluting companies from nonheavypolluting companies; this paper uses the PSM-DID model to explore the effect and mechanism of the "Guidelines" on corporate investment efficiency and examine the heterogeneous effects of the financial ecological environment on the relationship between the two to test the effectiveness and region of the "Guidelines" difference. The research contributions of this paper are mainly reflected in two aspects: (1) from the perspective of capital demand and capital utilization, it explains the impact of green credit on the investment efficiency of heavily polluting enterprises and further explores its internal mechanisms. (2) On the basis of the study of the relationship between the two, we further explored the impact of the heterogeneity of the financial ecological environment and provided an empirical reference for promoting the smooth implementation of green credit.

\section{Theoretical Analysis and Research Hypothesis}

2.1. Green Credit and Corporate Investment Efficiency. The purpose of the CBRC's "Guidelines" is to use the "green credit" of banking financial institutions to change the existing unreasonable credit structure and effectively stop both environmental and social risks to support the real economy with a higher standard and boost the adjustment of economic structure as well as the transformation of economic development mode. The "Guidelines" clearly stated that special credit guidelines should be formulated for restricted categories and industries with major environmental and social risks that are subject to national key regulation, implementation of differentiated and dynamic credit policies, and risk exposure management systems. After the "Guidelines" are promulgated, heavy-polluting companies may have the following two changes: (1) heavy-polluting companies focus on the influence of the "Guidelines" on them. Therefore, according to the assessment standards of environmental and social risks, they reestimate the future capital status and policy changes of the company and invest more cautiously. (2) Compared with non-heavy-polluting enterprises, under the limited capital level, heavy-polluting enterprises can reduce ineffective investment and improve investment efficiency; this is a necessary condition for heavypolluting enterprises to survive. Thus, how do these two aspects play a role in reality?

Concerning the first change, in the context of the country's increased environmental control, if heavily polluting companies continue their original investment plans, they will indeed face large fines or even suspend business for rectification, such as high environmental taxes, administrative fines, and and taking off the market, etc. Therefore, if heavy-polluting companies want to survive, they must reevaluate the future financial situation and policy changes, invest prudently, and allocate more resources to effective and efficient investment. In response to the second change, heavy-polluting companies are listed as restricted credit by financial institutions. Compared with non-heavy-polluting 
companies, it is more difficult to obtain financial support from financial institutions, and the availability of financing is significantly reduced. Affected by the "Guidelines," the amount of new loans that heavily polluting companies can obtain from banks has decreased. The scale of new loans is often difficult to cover the funding gap, and there is a risk of rupture of the capital chain. The phenomenon of excessive investment as mentioned above has improved. Mengze and Wei [16] confirmed that green credit can improve microeconomic efficiency from three aspects: reducing transaction costs, diversifying or reducing enterprise innovation risks, and supervising invested enterprises or projects. Therefore, this article believes that the green credit policy can form an "elimination mechanism" to improve the efficiency of internal capital allocation of heavily polluting enterprises and increase effective investment through the dynamic game between banks and enterprises. When the green credit policy is implemented, companies must disclose environmental information. The higher the quality of nonfinancial information is, the closer the amount of external financing obtained is to the optimal financing amount, which not only alleviates underinvestment but also avoids overinvestment $[17,18]$.

From the analysis mentioned above, this article puts forth the hypotheses listed as follows.

Hypothesis 1. After the "Guidelines" are issued, the investment efficiency of heavily polluting enterprises can be significantly improved compared to non-heavy-polluting enterprises.

How does green credit affect the investment efficiency of polluting companies? Peeters [19] believed that when the external macroeconomic uncertainty is high, the investment income of enterprises will become unstable. In this way, the capital needs of enterprises for projects under construction, investment in fixed assets, equipment renewal and transformation, scientific and technological development fees, and trial production of new products will be reduced; at the same time, under the condition of financing constraints, the manager's capital discretionary power will also be reduced along with the debt repayment responsibility so that the company will significantly reduce excessive investment behavior [20]. After the "Guidelines" were issued, the environmental and social risks faced by heavily polluting companies restricted the financing channels. Reduced planned investments, especially investment plans that originally had a negative impact on the ecological environment, are more likely to be forced to suspend or terminate, resulting in a substantial reduction in capital requirements and excessive investment behavior. On the contrary, enterprises will improve the efficiency of the use of existing funds, realize the improvement of microeconomic efficiency, increase effective investment, and accelerate the transformation and upgrading of enterprises. From the analysis mentioned above, this article puts forth the hypotheses listed as follows.

Hypothesis 2. The promulgation of the "Guidelines" has reduced the capital needs of heavily polluting companies and has improved the efficiency of the use of existing funds by heavily polluting companies, thereby affecting the investment efficiency of companies.

\subsection{The Impact of Financial Eco-Environment Heterogeneity.} The so-called "financial ecological environment" refers to a series of external environments and basic conditions for financial operation. According to its components, a good financial eco-environment is represented by high-speed economic development, a sound legal environment, highlevel social credibility, favorable financial sector independence, and sophisticated intermediary services and social security [21]. The financial eco-environment differs observably from region to region, but in terms of China, the overall financial eco-environment in the eastern part and eastern seaside region is good to some degree, while the ecoenvironment in the middle and western regions is comparatively poor. The conditions of financial eco-environment will significantly affect the allocative efficiency of financial resources in a region. For example, when the financial eco-environment in a certain area is better, the financial market, legal system, and integrity system in that area are significantly better than those in other areas, and the government of this area will lessen the interference in its market. It shows that the ability of banks to recognize the environmental information risks of borrowing companies and the ability to transform risk compensation are deeply affected by the financial eco-environment [22]. According to the research of previous scholars, the financial eco-environment can indeed significantly affect the allocative efficiency of credit capital. For example, Fazzari et al. [23] found that the financial ecology is positively related to the allocative efficiency of credit capital. Wang et al. [24] found that the effectiveness of financial development in promoting economic growth is affected by the external financial eco-environment in which it is located.

Narrow down to this paper, the impact of green credit on corporate investment efficiency is also surely affected by the financial eco-environment. On the one hand, with the effective implementation of the green credit policy, in areas with better financial eco-environment, the financial market, legal system, and integrity system are relatively complete, and heavily polluting enterprises are subject to stricter supervision and more rigid qualifications from the banks. At this time, under the circumstances of high financing constraints, the green credit policy can play a dynamic game with the banks and be more beneficial in promoting the improvement of the microeconomic efficiency in heavily polluting enterprises which will increase and investment efficiency with the amount of current funds. Meanwhile, when a bank evaluates the credit rating of an enterprise, its external environmental advantages are bound to be included in the assessment, which will increase the possibility of heavily polluting enterprises of obtaining bank loans, and the corresponding loan interest rates and guarantee fees will decrease together [25]. On the other hand, according to the previous analysis, in the areas with poor financial ecological environment, the absence of effective implementation of the 
green credit policy is due to the relatively low marketization, poor financial and legal system, weak resource allocation efficiency, etc., which may lead to the possibility of poor implementation; hence, its influence towards heavily polluting enterprises may lower. That is, in areas with poor financial ecological environment, the impact of the green credit policy on heavily polluting enterprises is very low; in addition, the bank's profit-driven motive will not restrict loans to heavily polluting enterprises so that the investments of heavily polluting enterprises will not be greatly affected. From the analysis mentioned above, this article puts forth the hypotheses listed as follows.

Hypothesis 3. The impact of green credit on the investment efficiency of enterprises is more obvious in areas with good financial and ecological environment.

\section{Research Design}

3.1. Sample Selection and Data Sources. This paper takes the A-share listed companies from 2008 to 2017 as the research object, drawing on the handling methods from Li and Feng [26] as well as Su and Lian [27] to ascertain the heavypolluting enterprises by calculating the pollution emission intensity in various industries, which is also the experimental group identified in this paper. The detailed steps are as follows.

Firstly, the industrial sulfur dioxide, smoke (powder), and liquid and solid waste emissions published by the National Bureau of Statistics every year through the China Statistical Yearbook are determined as pollutant emissions, and the pollutant emissions per unit of the output value of various industries are calculated, which can be expressed as $U E_{i j}=E_{i j} / O_{i}(i=1,2, \ldots, m ; j=1,2, \ldots, n)$, where $U E_{i j}$ is the emission per unit output value of pollutant emission $j$ of industry $i, E_{i j}$ is the total emission of pollutant emission $j$ of industry $i$, and $O_{i}$ is the total output value of industry $i$.

Secondly, standardize the discharge amount of pollutants per unit of the output value of various industries to make it within the range of $[0,1]$ :

$$
U E_{i j}^{\mathcal{S}}=\left[U E_{i j}-\min \left(U E_{j}\right)\right] /\left[\max \left(U E_{j}\right)-\min \left(U E_{j}\right)\right],
$$

where $U E_{i j}^{s}$ is the emission per unit output value of pollutant emission $j$ of the normalized industry $i, \min \left(U E_{j}\right)$ is the minimum emission of pollutant emission $j$ in all industries, and $\max \left(U E_{j}\right)$ is the maximum emission of pollutant emission $j$ in all industries.

Thirdly, the emission intensity $\gamma_{i}$ of industry $i$ is calculated, and the heavily polluting industry and non-heavily polluting industry are distinguished according to the median of $\gamma_{i}$ :

$$
\gamma_{i}=\sum_{j=1}^{n} U E_{i j}^{s} .
$$

Specifically, this paper has calculated the pollution emission intensity of various industries in 2011, the year before the publication of the Guidelines, based on the 2012 China Statistical Yearbook, and identified 20 heavily polluting industries such as power industry, thermal production and supply industries, and paper making and paper products' industry. Based on this, the paper eliminates the ST and *ST enterprises, financial enterprises, and major variables with serious missing and abnormal data and finally ascertains 18,349 observations, including 2852 listed companies which are divided into 1002 experimental groups of listed companies and a control group of 1850 listed companies. The financial eco-environment data in this paper come from China Regional Financial Eco-environmental Evaluation (2013-2014), and other financial and microsurvey data are from the database of Tai'an (CSMAR). To reduce the influence of extreme values on the research conclusion, the main continuous variables are processed with winsorization up and down to $1 \%$.

\subsection{Variable Definition}

3.2.1. Investment Efficiency. This paper draws on the research results from Richardson [28], AGcB et al. [29], and Wang et al. [30] to use the regression residuals of the following models to represent the investment efficiency of enterprises:

$$
\text { Invest }_{i, t}=\alpha_{0}+\alpha_{1} \text { Invest }_{i, t-1}+\alpha_{2} \text { Size }_{i, t-1}+\alpha_{3} \text { Cash }_{i, t-1}+\alpha_{4} \operatorname{Lev}_{i, t-1}+\alpha_{5} \text { Growth }_{i, t-1}+\alpha_{6} \operatorname{Return}_{i, t-1}+\alpha_{7} \text { Age }_{i, t-1}+\varepsilon_{i, t}
$$

In the formula, Invest represents a new investment, which is equal to (cash spent in the purchase and construction of fixed assets, intangible assets, and other longterm assets - net cash received from the fixed assets, intangible assets, and other assets' disposal) divided by total assets; Size stands for the size of the company, which is equal to the logarithm of the company's overall assets; Cash represents cash and cash equivalents, which is equal to (monetary capital plus tradable financial assets) divided by total assets; Lev represents the asset-liability ratio, which is equal to the company's total liabilities divided by total assets; Growth stands for investment opportunities, 
which is equal to the enterprise's increase rate of main business revenue; Return represents the enterprise's annual stock yield, which is equal to the annual stock return rate considering the cash bonus; and Age represents the enterprise's age, which is equal to the logarithm of the enterprise's listed years. Formula (3) regresses by year and industry to obtain the residual and takes the absolute value of the residual and records it as Absinvest, which is the investment efficiency. The larger the value is, the lower the investment efficiency and the higher the nonefficient investment of the enterprise owns.

3.2.2. Financial Ecology Environment. This paper makes conclusions on the research of Xie [31], Wei [32], etc., and uses all references of the financial eco-environment of different areas in China covered by the research group of the "Evaluation of Financial Ecology Environment of China" of the Institute of Finance, Chinese Academy of Social Sciences, to determine the level of financial ecological environment in each region. Since there are no data of the financial ecological environment comprehensive index in 2009, 2011, and 2012, this paper uses the practice of Deng Jianping and Zeng Yong for reference and uses data of 2008 to replace 2009, data of 2010 to replace the data of 2011, data of 2013 to replace the data of 2012, and data of 2014 to replace the data of 2015 to investigate the heterogeneous influence of financial ecological environment from 2008 to 2015. The specific practice is to find the average value of all references of financial eco-environment. If the comprehensive index of the financial eco-environment in a certain area is greater than the average value, then it is assigned to 1 , which demonstrates that the financial eco-environment in the region is relatively not bad. If the index is less than the average value, it is assigned to 0 , which shows that the financial and ecological environment in the region is relatively bad.

3.2.3. Control Variable. To reduce the impact of other factors, this paper draws on relevant research and sets the following control variables from the aspects of profitability, development capacity, operating capacity, and administration of an enterprise: corporate size, total asset return rate, sales growth rate, total asset turnover, the proportion of independent directors, and the firm's age; in addition to this, this paper further controls the year fixed effect and the industry fixed effect. The definitions of the main variables in this paper are shown in Table 1.

3.3. Model Selection. The double difference (DID) model is a policy evaluation model that is widely used in academia. The basic principle is to divide the sample into an experimental group affected by the policy and a control group not affected by the policy and then compare the experimental group and the control group to get the policy effect. The application of this model needs to satisfy that the experimental group and the control group have similar changing trends (common trends) before the implementation of the policy. However, due to the large differences between the heavy-polluting enterprises and non-heavy-polluting enterprises in this article in terms of different industry norms and management methods, there are certain self-selection problems in the research samples, which make the common trend assumption difficult to meet. In response to this problem, this paper draws on the propensity score matching proposed by Heckman et al. [33]. PSM can better solve the problem of sample selection bias, but it often ignores the endogeneity problem between variables, while DID can solve the endogeneity problem through difference and obtain the policy processing effect, but it has certain defects in solving the sample bias problem. Therefore, a combination of the two methods is chosen to evaluate the impact of green credit on the investment efficiency of enterprises.

The basic idea of the model is as follows: in the control group not affected by the policy, find company $j$ (matching) that is very similar to company $i$ in the experimental group so that $i \approx j$; repeated operations can be matched to a set with a common value range $S p$; the experimental group and the control group of this set can better meet the common trend assumption in the double difference. Propensity score matching is to match individuals with the same propensity score together. Typical matching methods include nearest neighbor matching, radius matching, and kernel matching. This paper uses the kernel matching method to determine the weight, and its expression is shown in the following:

$$
\omega(i, j)=\frac{K\left[\left(x_{j}-x_{i}\right) / h\right]}{\sum_{k: D_{k=0}} K\left[\left(x_{k}-x_{i}\right) / h\right]},
$$

where $h$ is the designated bandwidth and $K(\cdot)$ is the kernel function.

The specific PSM-DID process can be divided into the following steps:

(1) Using the logit model to estimate the propensity score:

$$
P\left(Z_{i}\right)=P\left(D_{i}=1 \mid Z_{i}\right)=\frac{\Lambda\left(Z_{i}^{\prime} \beta\right)}{\left(1+\exp \left(Z_{i}^{\prime} \beta\right)\right)} .
$$

(2) Calculating the changes in investment efficiency of heavily polluting companies and non-heavy-polluting companies before and after the issuance of the Guidelines.

(3) Subtracting the change in investment efficiency of heavy-polluting enterprises before and after the issuance of the Guidelines minus the change in investment efficiency of matching non-heavy-polluting enterprises before and after the issuance of the Guidelines to obtain the average treatment effect after the issuance of the Guidelines, as shown in formula (3.6). 
TABle 1: Main definitions of variables.

\begin{tabular}{|c|c|c|}
\hline Variable & Symbol & Definition \\
\hline Investment efficiency & Absinvest & $\begin{array}{l}\text { According to the absolute value of the residual of the regression model, the larger the } \\
\text { value gets, the lower the investment efficiency and the higher the nonefficient investment } \\
\text { are }\end{array}$ \\
\hline $\begin{array}{l}\text { Is it heavily polluting } \\
\text { enterprise? }\end{array}$ & Pollution & $\begin{array}{c}\text { Dummy variable, Pollution }=1 \text {, which indicates heavily polluting enterprise; } \\
\text { Pollution }=0 \text {, which indicates non-heavily polluting enterprise }\end{array}$ \\
\hline Policy implementation time & After & 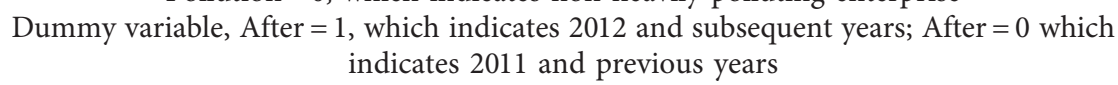 \\
\hline $\begin{array}{l}\text { Difference-in-differences } \\
\text { variable }\end{array}$ & ollution $\times$ After & he product of Pollution and After indicates the net effect of policy \\
\hline $\begin{array}{l}\text { Financial ecology } \\
\text { environment }\end{array}$ & $\mathrm{Fe}$ & $\begin{array}{c}\text { Dummy variable, Findex }=1 \text {, which indicates the regional financial ecology environment } \\
\text { is relatively good; Findex }=0 \text {, which indicates the regional financial ecology environment } \\
\text { is relatively bad }\end{array}$ \\
\hline Cor & & The logarithm o \\
\hline Total & & \\
\hline Sales growth rate & Growth & $\begin{array}{l}\text { (The current amount of business revenue of the current year - the sync } \\
\text { of business revenue of last year)/the synchronous amount of business re }\end{array}$ \\
\hline Total & Tat & Business revenue/(total asset + final balance of initial balance $) / 2$ \\
\hline $\begin{array}{l}\text { Proportion of independent } \\
\text { directors }\end{array}$ & Ids & Number of independent directors/number of directors \\
\hline Firm's age & Age & The logarithm of the enterprise's listed years \\
\hline
\end{tabular}

$$
A \widehat{T} T=\frac{1}{N^{*}} \sum_{i: i \in I_{1} \cap S_{p}}\left[\left(Y_{T} t_{1} i-Y_{T} t_{0} i\right)-\sum_{j: j \in I_{0} \cap S_{p}} w(i, j)\left(Y_{C} t_{1} i-Y_{C} t_{0} i\right)\right] .
$$

In the formula, $T$ represents a heavily polluting company in the experimental group, $C$ represents a non-heavy-polluting company in the control group, $t_{0}$ represents before the release of the Guidelines, $t_{1}$ represents after the release of the Guidelines, $i$ represents a company in the experimental group, $j$ represents a company in the control group, $w(i, j)$ represents the weight after core matching, $I_{1}$ represents the experimental group company before matching, $I_{0}$ represents the control group company before matching, and $N^{*}$ represents the number of enterprises in the experimental group in the set $I I_{1} \cap S_{p}$.

Based on the above analysis, this paper sets the regression model based on the PSM-DID method which is as follows:

$$
\text { Absinvest }_{i t}=\beta_{0}+\beta_{1} \text { Pollution }_{i t}+\beta_{2} \text { After }_{i t}+\beta_{3} \text { Pollution }_{i t} \times \text { After }_{i t}+\beta_{4} \text { Control }_{i t}+\varepsilon_{i t} \text {. }
$$

In the formula, Control represents the control variable, which includes the control of the fixed effect of the year and the industry; the coefficient $\beta_{3}$ represents the net effect of the policy implementation on the experimental group. If $\beta_{3}<0$, it means that the promulgation of the "Guidelines" has reduced the inefficient investment of heavily polluting enterprises, that is, improved the investment efficiency of heavily polluting enterprises.

In addition, to further explore the dynamic effects of policy implementation, we study the expected effects and lag effects before and after the issuance of the "Guidelines." This paper draws on the practice of Fan et al. [34], and the following model is constructed:

$$
\begin{aligned}
\text { Absinvest }_{i t}= & \eta_{0}+\eta_{1} \text { Pollution }_{i t}+\eta_{2} \text { After }_{i t}+\sum_{t=2008}^{t=2011} \eta_{t} \text { Pollution }_{i t} \times \text { Preyear }_{t} \\
& +\eta_{2012} \text { Pollution }_{i t} \times \text { Current }_{2012}+\sum_{t=2013}^{t=2017} \eta_{t} \text { Pollution }_{i t} \times \text { Postyear }_{t} \\
& +\eta_{3} \text { Control }_{i t}+\varepsilon_{i t} .
\end{aligned}
$$




\section{Outcomes of Practice}

4.1. Descriptive Statistics of the Main Variables. Tables 2 and 3 list the descriptive statistics of the main variables in this article. It can be seen from Table 2 that the average investment efficiency of the full sample of companies is 0.0238 , indicating that the overall investment efficiency of listed companies in my country is relatively good, and the inefficient investment is not serious. For the heavy-polluting companies in the experimental group, before the "Guidelines" were issued, the average investment efficiency was 0.0316. After the promulgation of the Guidelines, the average investment efficiency was 0.0244 , a decrease of $23 \%$. To a certain extent, the promulgation of the Guidelines has greatly reduced the inefficient investment of heavily polluting enterprises and improved the investment efficiency. The mean value of the investment efficiency of non-heavypolluting companies in the control group before the issuance of the Guidelines was 0.0259. The average value after the issuance of the Guidelines is 0.0210 , a decrease of $19 \%$, which shows that the inefficiency investment of all types of enterprises has decreased after the issuance of the Guidelines. Compared with non-heavy-polluting enterprises, the impact of inefficient investment by heavy-polluting enterprises is greater. The specific causality and internal mechanism need to be empirically tested.

\subsection{Model Checking}

\subsubsection{Impact of Green Credit on Investment Efficiency}

(1) Average Treatment Effect. We evaluated the influence of green credit policies on the inefficient investment of companies that cause serious pollution through a panel regression model, with the results listed in Table 4. Result (1) includes only the key explanatory variable, namely, inefficient investment, and the coefficient is significantly negative, indicating that the promulgation of the Guidelines has indeed significantly reduced the inefficient investment of heavily polluting enterprises, improved the efficiency of capital allocation, and thereby increased investment efficiency; so, Hypothesis 1 is not rejected. On the basis of model 1 , control variables are gradually added to the model to form results (2)-(7). Clearly, the coefficient of Pollution $\times$ After is still negative, which further supports the conclusion of Hypothesis 1.

(2) Dynamic Action. To study the dynamic effects of green credit on investment efficiency, this paper further uses a hybrid panel model, with the results shown in Table 5. The dynamic panel regression model shows that, in the year the Guidelines were issued, the implementation of the policy did not have a significant impact on the investment efficiency of heavily polluting enterprises. The main reason is that financial institutions have a time lag in formulating their own credit policies in accordance with the Guidelines. The investment efficiency of heavily polluting enterprises is mainly calculated by the investment projects, and it takes a certain amount of time to change the investment plan. Since 2013, the net effect of policy implementation has been significantly negative, at least at the level of $1 \%$, indicating that the Guidelines have shown microeffects since the second year of policy promulgation, and the inefficient investment of heavily polluting enterprises has been significantly reduced. The regression coefficient in 2013 was -0.0071 , and it was significant at the $1 \%$ level. That is to say, after the "Guidelines" were issued, the effect of policy implementation in 2013 was the most obvious. Although the absolute value of the regression coefficient decreased slightly in 2014 compared with 2013, the absolute value of the regression coefficient has increased year by year since 2014, which also means that the implementation process of the Guidelines has stabilized, and the degree of influence has gradually increased.

(3) Test Based on the PSM-DID Model. To reduce the systematic differences between the heavily polluting enterprises in the experimental group and the non-heavily polluting enterprises in the common trend assumption and obtain more robust research conclusions, this paper further tests the above conclusions by using PSM-DID. If there is no important dissimilarity between the experimental group and the control group after the matching, the propensity score matching needs to meet the balance between the nature hypothesis and the common support hypothesis. The hypothesis of equilibrium property means that there is no important dissimilarity between the experimental group and the control group after matching, while the common support hypothesis means that both the experimental group and the control group have enough overlapping areas in the value range.

The matching of the propensity score can be completed in the following two steps. First, the appropriate matching variables are selected, the conditional distribution of variables is estimated, that is, green credit, and then the propensity score is calculated, where the propensity score refers to the probability that the sample enterprise will be affected by the guidance after controlling the observable factors. Second, according to the calculated tendency score and the variable green credit in the first step, the conditional distribution of the investment efficiency of the resulting variable is estimated. Due to the propensity score covering the "synthesis" of the influence of all matching variables on investment efficiency, the consistency of the control propensity score can effectively guarantee the independence of green credit and investment efficiency, which greatly reduces the estimation bias caused by the difference of control variables between different enterprises.

Referring to the related study and the selection of this paper, finally, the enterprise size (Size), the asset-liability ratio (Lev), the growth rate of business income (Growth), the concentration of equity (Shrcr), and the total asset turnover rate (Tat) are determined as matching variables; in addition, the year is further controlled. Table 6 shows the balance property test results of each matching variable after kernel matching. 
TABle 2: Description of the main variables.

\begin{tabular}{|c|c|c|c|c|c|}
\hline Variable & $N$ & Mean & $\mathrm{SD}$ & Min & Max \\
\hline Absinvest & 18,349 & 0.0238 & 0.0247 & 0.0002 & 0.1361 \\
\hline Size & 18,349 & 22.0830 & 1.2516 & 19.7200 & 25.8306 \\
\hline Roa & 18,349 & 0.0418 & 0.0531 & -0.1429 & 0.2107 \\
\hline Lev & 18,349 & 0.4444 & 0.2077 & 0.0530 & 0.8790 \\
\hline Growth & 18,349 & 0.1934 & 0.4504 & -0.5657 & 2.8958 \\
\hline Tat & 18,349 & 0.6717 & 0.4683 & 0.0651 & 2.6503 \\
\hline Ids & 18,287 & 0.3720 & 0.0530 & 0.3077 & 0.5714 \\
\hline Age & 18,349 & 2.1714 & 0.7286 & 0.6931 & 3.2189 \\
\hline
\end{tabular}

TABle 3: Descriptive statistical analysis of the main variables before and after the policy.

\begin{tabular}{|c|c|c|c|c|c|c|c|c|c|c|c|c|}
\hline \multirow[b]{3}{*}{ Variable } & \multicolumn{6}{|c|}{ Experimental group } & \multicolumn{6}{|c|}{ Control group } \\
\hline & \multicolumn{3}{|c|}{ Before } & \multicolumn{3}{|c|}{ After } & \multicolumn{3}{|c|}{ Before } & \multicolumn{3}{|c|}{ After } \\
\hline & $\begin{array}{c}\text { Number } \\
\text { of } \\
\text { samples }\end{array}$ & $\begin{array}{l}\text { Mean } \\
\text { value }\end{array}$ & $\begin{array}{l}\text { Standard } \\
\text { deviation }\end{array}$ & $\begin{array}{c}\text { Number } \\
\text { of } \\
\text { samples }\end{array}$ & $\begin{array}{l}\text { Mean } \\
\text { value }\end{array}$ & $\begin{array}{l}\text { Standard } \\
\text { deviation }\end{array}$ & $\begin{array}{c}\text { Number } \\
\text { of } \\
\text { samples }\end{array}$ & $\begin{array}{l}\text { Mean } \\
\text { value }\end{array}$ & $\begin{array}{l}\text { Standard } \\
\text { deviation }\end{array}$ & $\begin{array}{c}\text { Number } \\
\text { of } \\
\text { samples }\end{array}$ & $\begin{array}{l}\text { Mean } \\
\text { value }\end{array}$ & $\begin{array}{l}\text { Standard } \\
\text { deviation }\end{array}$ \\
\hline Absir & 2126 & 0.0316 & 0.0283 & & 0.0 & 007 & 2880 & 0. & 0.0 & 8594 & 0.0210 & 0.0230 \\
\hline Size & 2126 & 21.9186 & 1.2182 & 4749 & 22.2319 & 1.2445 & 2880 & 21.7705 & 1.1741 & 8594 & 22.1461 & 1.2667 \\
\hline Roa & 2126 & 0.0454 & 0.0649 & 4749 & 0.0419 & 0.0580 & 2880 & 0.0474 & 0.0490 & 8594 & 0.0391 & 0.0480 \\
\hline Lev & 2126 & 0.4812 & 0.1970 & 4749 & 0.4207 & 0.2084 & 2880 & 0.4773 & 0.1989 & 8594 & 0.4374 & 0.2102 \\
\hline Growth & 2126 & 0.1959 & 0.3507 & 4749 & 0.1470 & 0.3993 & 2880 & 0.2294 & 0.4798 & 8594 & 0.2063 & 0.4856 \\
\hline Tat & 2126 & 0.7949 & 0.4749 & 4749 & 0.6809 & 0.4396 & 2880 & 0.7461 & 0.5374 & 8594 & 0.6113 & 0.4468 \\
\hline Ids & 2097 & 0.3649 & 0.0513 & 4749 & 0.3709 & 0.0517 & 2849 & 0.3666 & 0.0508 & 8592 & 0.3761 & 0.0545 \\
\hline Age & 2126 & 2.1416 & 0.6388 & 4749 & 2.2627 & 0.7043 & 2880 & 2.1319 & 0.7259 & 8594 & 2.1416 & 0.7588 \\
\hline
\end{tabular}

TABLE 4: The impact of green credit on investment efficiency.

\begin{tabular}{|c|c|c|c|c|c|c|c|}
\hline & $\begin{array}{l}(1) \\
M 1\end{array}$ & $\begin{array}{l}(2) \\
\text { M2 }\end{array}$ & $\begin{array}{l}\text { (3) } \\
\text { M3 }\end{array}$ & $\begin{array}{l}(4) \\
\text { M4 }\end{array}$ & $\begin{array}{l}(5) \\
\text { M5 }\end{array}$ & $\begin{array}{l}(6) \\
\text { M6 }\end{array}$ & $\begin{array}{l}\text { (7) } \\
\text { M7 }\end{array}$ \\
\hline Pollution & $\begin{array}{c}0.0165^{* * *} \\
(0.0020)\end{array}$ & $\begin{array}{c}0.0196^{* * *} \\
(0.0022)\end{array}$ & $\begin{array}{c}0.0196^{* * *} \\
(0.0021)\end{array}$ & $\begin{array}{c}0.0199^{* * *} \\
(0.0021)\end{array}$ & $\begin{array}{c}0.0190^{* * *} \\
(0.0021)\end{array}$ & $\begin{array}{c}0.0191^{* * *} \\
(0.0022)\end{array}$ & $\begin{array}{c}0.0194^{* * *} \\
(0.0020)\end{array}$ \\
\hline After & $\begin{array}{c}0.0085^{* * *} \\
(0.0010)\end{array}$ & $\begin{array}{c}-0.0067^{* * *} \\
(0.0010)\end{array}$ & $\begin{array}{c}-0.0068^{* * *} \\
(0.0010)\end{array}$ & $\begin{array}{c}-0.0069^{* * *} \\
(0.0010)\end{array}$ & $\begin{array}{c}-0.0079^{* * *} \\
(0.0010)\end{array}$ & $\begin{array}{c}-0.0082^{* * *} \\
(0.0010)\end{array}$ & $\begin{array}{c}-0.0079^{* * *} \\
(0.0010)\end{array}$ \\
\hline Pollution $\times$ After & $\begin{array}{c}0.0029^{* * *} \\
(0.0010)\end{array}$ & $\begin{array}{c}-0.0030^{* * *} \\
(0.0010)\end{array}$ & $\begin{array}{c}-0.0030^{* * *} \\
(0.0010)\end{array}$ & $\begin{array}{c}-0.0030^{* * *} \\
(0.0010)\end{array}$ & $\begin{array}{c}-0.0029^{* * *} \\
(0.0010)\end{array}$ & $\begin{array}{c}-0.0028^{* * *} \\
(0.0010)\end{array}$ & $\begin{array}{c}-0.0026^{* * * *} \\
(0.0010)\end{array}$ \\
\hline Size & & $\begin{array}{c}-0.0020^{* * *} \\
(0.0002)\end{array}$ & $\begin{array}{c}-0.0021^{* * *} \\
(0.0002)\end{array}$ & $\begin{array}{c}-0.0021^{* * *} \\
(0.0002)\end{array}$ & $\begin{array}{c}-0.0020^{* * *} \\
(0.0002)\end{array}$ & $\begin{array}{c}-0.0020^{* * *} \\
(0.0002)\end{array}$ & $\begin{array}{r}-0.0015^{* * *} \\
(0.0002)\end{array}$ \\
\hline Roa & & & $\begin{array}{c}0.0147^{* * *} \\
(0.0037)\end{array}$ & $\begin{array}{c}0.0109^{* * *} \\
(0.0038)\end{array}$ & $\begin{array}{c}0.0158^{* * *} \\
(0.0038)\end{array}$ & $\begin{array}{c}0.0158^{* * *} \\
(0.0038)\end{array}$ & $\begin{array}{l}0.0069^{*} \\
(0.0039)\end{array}$ \\
\hline Growth & & & & $\begin{array}{c}0.0020^{* * * *} \\
(0.0005)\end{array}$ & $\begin{array}{c}0.0023^{* * *} \\
(0.0005)\end{array}$ & $\begin{array}{c}0.0023^{* * *} \\
(0.0005)\end{array}$ & $\begin{array}{c}0.0021^{* * *} \\
(0.0005)\end{array}$ \\
\hline Tat & & & & & $\begin{array}{c}-0.0037^{* * *} \\
(0.0005)\end{array}$ & $\begin{array}{c}-0.0036^{* * *} \\
(0.0005)\end{array}$ & $\begin{array}{c}-0.0032^{* * *} \\
(0.0005)\end{array}$ \\
\hline Ids & & & & & & $\begin{array}{c}0.0063^{* * *} \\
(0.0034)\end{array}$ & $\begin{array}{c}0.0046 \\
(0.0034)\end{array}$ \\
\hline Age & & & & & & & $\begin{array}{r}-0.0033^{* * *} \\
(0.0003)\end{array}$ \\
\hline cons & $\begin{array}{c}0.0164^{* * *} \\
(0.0018)\end{array}$ & $\begin{array}{c}0.0591^{* * *} \\
(0.0038)\end{array}$ & $\begin{array}{c}0.0599^{* * *} \\
(0.0038)\end{array}$ & $\begin{array}{c}0.0603^{* * *} \\
(0.0038)\end{array}$ & $\begin{array}{c}0.0598^{* * *} \\
(0.0038)\end{array}$ & $\begin{array}{c}0.0580^{* * *} \\
(0.0040)\end{array}$ & $\begin{array}{c}0.0546^{* * *} \\
(0.0039)\end{array}$ \\
\hline$R^{2}$ adjusted & 0.0588 & 0.0669 & 0.0678 & 0.0690 & 0.0722 & 0.0726 & 0.0795 \\
\hline$F$ & 26.7022 & 29.9979 & 29.7287 & 29.8250 & 30.0947 & 29.6057 & 31.0591 \\
\hline$N$ & 18349 & 18349 & 18349 & 18349 & 18349 & 18287 & 18287 \\
\hline
\end{tabular}

Notes: standard deviations are in parentheses; ${ }^{*}, * *$ and ${ }^{* * *}$ indicate significant differences at $p<0.01, p<0.05$, and $p<0.001$, respectively.

Therefore, there is no exact method to determine the matching effect, but the smaller the absolute value of the standard deviation after matching, the better the matching effect. Rosenbaum and Rubin [35] pointed out that if the absolute value of the standard deviation between the matched variables is greater than $20 \%$, the matching effect is not good. Chang et al. [36] pointed out that if the absolute value of standard deviation between variables after matching 
Table 5: Dynamic effect of green credit on investment efficiency.

\begin{tabular}{lc}
\hline Variable & Panel regression model \\
\hline Pollution $\times$ Preyear 2008 & -0.0019 \\
& $(0.0024)$ \\
Pollution $\times$ Preyear 2009 & 0.0000 \\
& $()$. \\
Pollution $\times$ Preyear 2010 & $-0.0090^{* * *}$ \\
& $(0.0022)$ \\
Pollution $\times$ Preyear 2011 & -0.0032 \\
& $(0.0022)$ \\
Pollution $\times$ Current 2012 & $-0.0035^{*}$ \\
& $(0.0021)$ \\
Pollution $\times$ Postyear 2013 & $-0.0071^{* * *}$ \\
& $(0.0020)$ \\
Pollution $\times$ Postyear 2014 & $-0.0055^{* * *}$ \\
& $(0.0020)$ \\
Pollution $\times$ Postyear 2015 & $-0.0062^{* * *}$ \\
& $(0.0019)$ \\
Pollution $\times$ Postyear 2016 & $-0.0066^{* * *}$ \\
& $(0.0019)$ \\
Pollution $\times$ Postyear 2017 & $-0.0079^{* * *}$ \\
& $(0.0019)$ \\
& cons \\
\hline$R^{2}$ adjusted & $0.0539^{* * *}$ \\
$F$ & $(0.0039)$ \\
\hline
\end{tabular}

is less than $5 \%$, then the matching effect is reliable and acceptable. To sum up, the absolute value of the standard deviation of the matching variable, enterprise scale, assetliability ratio, operating income growth rate, equity concentration, and total asset turnover rate after matching is less than $5 \%$, so the matching variable and matching method selected in this paper can be considered appropriate, and the matching estimation result is also reliable. On the contrary, from the point of view of the mean difference between the experimental group and the control group before and after matching, there is a significant difference in the mean value of matching variables before matching and no important dissimilarity after matching, which also shows that the matching estimation results in this paper are reliable.

The above test shows that if the propensity score matching the balance property hypothesis is satisfied, then the common support hypothesis requires that the propensity scores of the experimental group and the control group should have enough common value range; that is to say, the propensity scores of the experimental group and the control group should have similar distribution characteristics. Figure 1 is the result of the common support hypothesis test. After the kernel matching, the observation values are in the common value range, so the observation values after matching and in the common support range will not affect the samples.
In summary, after matching the propensity scores, the data of the heavy-polluting enterprises in the experimental group and the non-heavy-polluting enterprises in the control group have been well balanced. At this time, the heavy-polluting enterprises and the non-heavy-polluting enterprises have similar characteristics, thus ensuring the common trend assumption in the DID model is satisfied. The table lists the test results of the PSM-DID model. It is not difficult to see from Table 7 that the double difference term is -0.001 , which is significant at the $10 \%$ level, making it clear that the promulgation of the "Guidelines" has reduced the inefficiency of enterprises' investment; compared with nonheavy-polluting companies, the impact of heavy-polluting companies is greater.

4.2.2. Mechanism Test of Green Credit Affecting Investment Efficiency. The previous research shows that, after the Guidelines were proclaimed, heavy-polluting companies have reduced inefficient investment and improved investment efficiency compared with non-heavy-polluting enterprises. We will further examine the mechanism by which the Guidelines affect the investment efficiency of heavily polluting enterprises. After the "Guidelines" were issued, heavy-polluting companies lacked sources of funds. Under the influence of national policies, the planned investment of heavy-polluting companies may decrease. In particular, investment plans that originally had a negative impact on the ecological environment are more likely to be forced to suspend or terminate, resulting in a substantial reduction in capital requirements. Instead, more attention is paid to the use of existing funds, which improves the efficiency of the use of existing funds, thereby reducing inefficient investment and improving investment efficiency. To verify the accuracy of this hypothesis, this article draws on the research methods by Baron and Kenny [37] and Satterthwaite [38]. It is checked through the following three steps: in the first step, the difference item is used to regress the capital demand; if the regression coefficient of the difference item is significant, it indicates that the promulgation of the "Guidelines" has significantly affected the capital needs of heavily polluting enterprises. The second step is to use the difference term to regress the investment efficiency; assuming that the regression coefficient of the difference term is significant, it means that the promulgation of the "Guidelines" has affected the investment efficiency of heavily polluting enterprises; since this step has been completed before, it will be omitted. The third step is to use the difference term and capital demand to regress the investment efficiency; if the difference term coefficient is no longer significant or the significance is reduced or significant, but the absolute value of the coefficient is reduced, it means that the promulgation of the "Guidelines" will indeed affect the enterprise through the capital demand investment efficiency. According to the above steps, this article designs the following model: 
TABLE 6: Test of the equilibrium property of matching variables.

\begin{tabular}{|c|c|c|c|c|c|c|}
\hline \multirow{2}{*}{\multicolumn{2}{|c|}{ Variable }} & \multicolumn{2}{|c|}{ Mean } & \multirow{2}{*}{ Standard deviation (\%) } & \multirow{2}{*}{ Standard deviation reduction margin (\%) } & \multirow{2}{*}{$T$-statistics } \\
\hline & & Experimental group & Control group & & & \\
\hline \multirow{2}{*}{ Size } & Before & 22.135 & 22.052 & 6.7 & \multirow{2}{*}{70.6} & $4.36^{* * *}$ \\
\hline & After & 22.135 & 22.111 & 2.0 & & 1.13 \\
\hline \multirow{2}{*}{ Lev } & Before & 0.4394 & 0.4475 & -3.9 & \multirow{2}{*}{94.0} & $-2.54^{* *}$ \\
\hline & After & 0.4394 & 0.4398 & -0.2 & & -0.14 \\
\hline \multirow{2}{*}{ Growth } & Before & 0.1621 & 0.2121 & -11.4 & \multirow{2}{*}{94.0} & $-7.29^{* * *}$ \\
\hline & After & 0.1617 & 0.1587 & 0.7 & & 0.45 \\
\hline \multirow{2}{*}{ Shrcr } & Before & 0.3599 & 0.3452 & 9.8 & \multirow{2}{*}{75.1} & $6.44^{* * *}$ \\
\hline & After & 0.3599 & 0.3562 & 2.4 & & 1.42 \\
\hline \multirow{2}{*}{ Tat } & Before & 0.7162 & 0.6451 & 15.3 & \multirow{2}{*}{81.3} & $9.97^{* * *}$ \\
\hline & After & 0.7162 & 0.7030 & 2.9 & & 1.59 \\
\hline
\end{tabular}

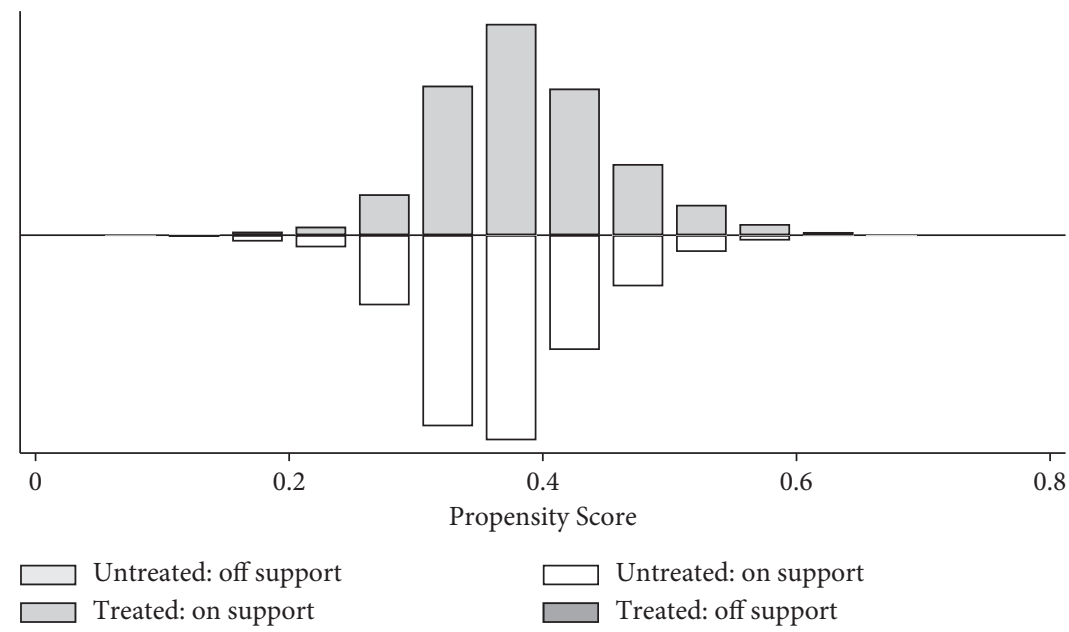

(a)

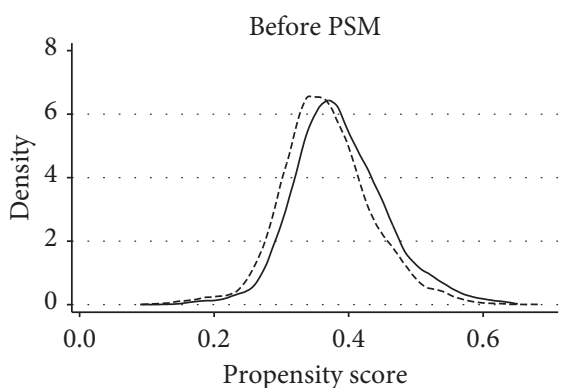

- Treated

- - - Untreated

(b)

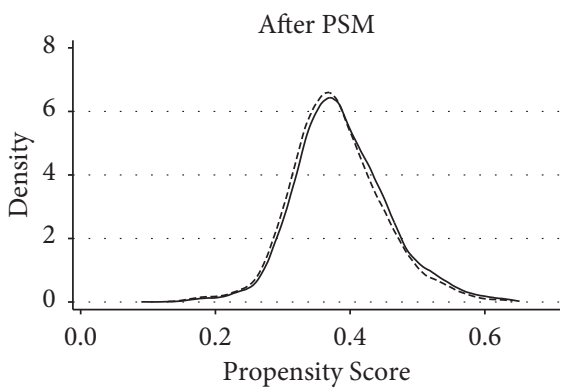

- Treated

- - - Untreated

(c)

Figure 1: Continued. 


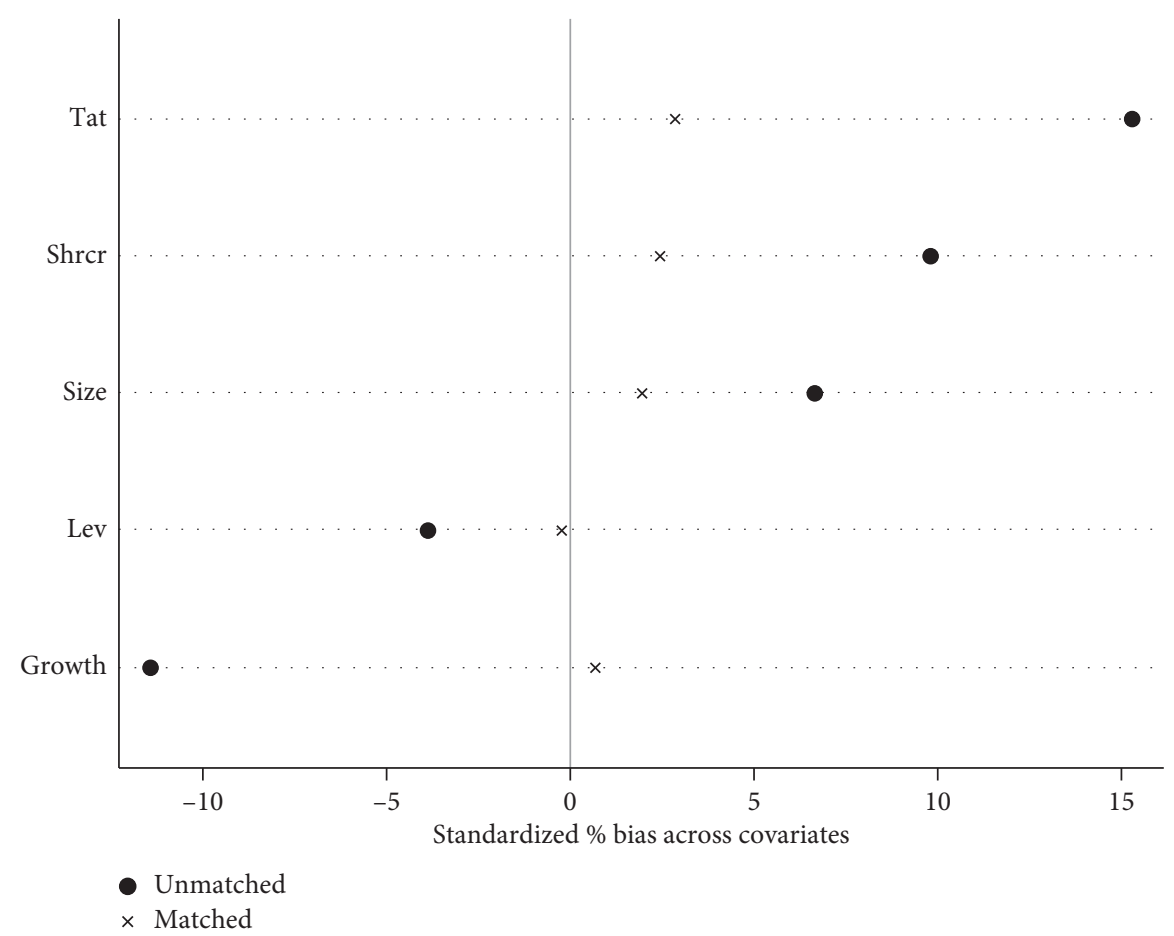

(d)

Figure 1: Common support hypothesis testing.

TABLE 7: Test results of PSM-DID.

\begin{tabular}{|c|c|c|c|c|c|c|c|}
\hline \multirow{2}{*}{ Variable } & \multicolumn{3}{|c|}{ Before the promulgation of the Guidelines } & \multicolumn{3}{|c|}{ After the promulgation of the Guidelines } & \multirow{2}{*}{ Difference-in-difference } \\
\hline & Experimental group & Control group & Difference & Experimental group & Control group & Difference & \\
\hline Absinvest & 0.032 & 0.026 & 0.006 & 0.024 & 0.019 & 0.005 & -0.001 \\
\hline & & & 0.001 & & & 0.001 & 0.001 \\
\hline$|t|$ & & & 8.88 & & & 9.04 & 1.71 \\
\hline$p>|t|$ & & & $\leq 0.001^{* * *}$ & & & $\leq 0.001^{* * *}$ & $0.087^{*}$ \\
\hline
\end{tabular}

Standard deviations are in parentheses; ${ }^{*},{ }^{* *}$, and ${ }^{* * *}$ indicate significant differences at $p<0.01, p<0.05$, and $p<0.001$, respectively.

$$
\begin{aligned}
D_{i t}= & \delta_{0}+\delta_{1} \text { Pollution }_{i t}+\delta_{2} \text { After }_{i t}+\delta_{3} \text { Pollution }_{i t} \times \text { After }_{i t}+\delta_{4} \text { Control }_{i t}+\varepsilon_{i t}, \\
\text { Absinvest }_{i t}= & \mu_{0}+\mu_{1} \text { Pollution }_{i t}+\mu_{2} \text { After }_{i t}+\mu_{3} \text { Pollution }_{i t} \times \text { After }_{i t} \\
& +\mu_{4} D_{i t}+\mu_{5} \text { Control }_{i t}+\varepsilon_{i t} .
\end{aligned}
$$

Equation (4.1) is step one, and equation (4.2) is step three, where $D_{i t}$ represents the capital requirement. Drawing on the research of Wang and Song (2014), the funding requirements in this article include liquidity funding requirements (Dld) and long-term funding requirements (Dfd). Liquidity capital requirements refer to the short-term or daily business needs of the company; the uncertainty of the company's liquidity capital quota will affect the company's future financing behavior and then affect the company's investment behavior. Liquidity requirements $=$ short-term borrowing + short-term bonds payable + additional issuance and allotment based on short-term demand-short-term borrowing based on long-term demand. Long-term capital demand refers to the long-term capital needs of the company or project construction and investment. The company's project investment generally comes from long-term funds, and the increase in long-term capital uncertainty will inevitably reduce the company's investment behavior. Long-term funding needs = long-term borrowing + additional issuance and allotment based on long-term needs-long-term borrowing based on short-term needs. The capital requirements in this article are all measured by changes in capital requirements, which are changes in capital requirements $=$ (current capital requirements-preliminary capital requirements)/preliminary capital requirements. 
TABLE 8: Mechanism of green credit affecting investment efficiency.

\begin{tabular}{|c|c|c|c|}
\hline & $\begin{array}{c}(1) \\
\text { Liquidity demand }\end{array}$ & $\begin{array}{c}\text { (2) } \\
\text { Long-term funding needs }\end{array}$ & $\begin{array}{c}\text { (3) } \\
\text { Investment efficiency }\end{array}$ \\
\hline Pollution & $\begin{array}{l}0.2564^{*} \\
(0.1472)\end{array}$ & $\begin{array}{l}-0.0713 \\
(0.1977)\end{array}$ & $\begin{array}{c}0.0070^{* * *} \\
(0.0017)\end{array}$ \\
\hline After & $\begin{array}{l}-0.1225 \\
(0.1280)\end{array}$ & $\begin{array}{c}-1.1532^{* * *} \\
(0.2045)\end{array}$ & $\begin{array}{c}-0.0063^{* * *} \\
(0.0017)\end{array}$ \\
\hline Pollution $\times$ After & $\begin{array}{c}-0.1257^{*} \\
(0.0700)\end{array}$ & $\begin{array}{l}-0.0634 \\
(0.1050)\end{array}$ & $\begin{array}{l}-0.0017 \\
(0.0010)\end{array}$ \\
\hline Dld & & & $\begin{array}{c}0.0003^{* * *} \\
(0.0001)\end{array}$ \\
\hline _cons & $\begin{array}{l}-7.6161^{* * *} \\
(1.1241)\end{array}$ & $\begin{array}{c}-12.8218^{* * *} \\
(1.6411)\end{array}$ & $\begin{array}{c}0.0730^{* * *} \\
(0.0132)\end{array}$ \\
\hline$R^{2}$ adjusted & 0.0227 & 0.0162 & 0.0441 \\
\hline$F$ & 11.1497 & 8.7302 & 30.5698 \\
\hline$N$ & 18287 & 18287 & 18287 \\
\hline
\end{tabular}

Standard deviations are in parentheses; ${ }^{*},{ }^{* *}$, and ${ }^{* * *}$ indicate significant differences at $p<0.01, p<0.05$, and $p<0.001$, respectively.

TABle 9: Test of the heterogeneity of the financial ecological environment.

\begin{tabular}{lcc}
\hline \multirow{2}{*}{ Variable } & \multicolumn{2}{c}{ Mixed panel model } \\
& $\mathrm{Fe}=1$ & $\mathrm{Fe}=0$ \\
& $(1)$ & $(2)$ \\
\hline \multirow{2}{*}{ Pollution } & $0.0128^{* * *}$ & $0.0135^{* * *}$ \\
& $(0.0036)$ & $(0.0034)$ \\
After & -0.0017 & $-0.0054^{* * *}$ \\
& $(0.0013)$ & $(0.0020)$ \\
Pollution $\times$ After & $-0.0035^{* *}$ & -0.0014 \\
Control & $(0.0012)$ & $(0.0015)$ \\
Year & Control & Control \\
Industry_cons & Control & Control \\
& Control & Control \\
$R^{2}$ adjusted & $0.0505^{* * *}$ & $0.0623^{* * *}$ \\
$R^{2}$ adjusted & $(0.0052)$ & $(0.0069)$ \\
$F$ & 0.0844 & 0.0669 \\
\hline
\end{tabular}

Standard deviations are in parentheses; ${ }^{*},{ }^{* *}$, and ${ }^{* * *}$ indicate significant differences at $p<0.01, p<0.05$, and $p<0.001$, respectively.

Table 8 shows the test results of the mechanism for green credit affecting investment efficiency. Judging from the coefficients of the difference terms of models (1) and (2), the promulgation of the Guidelines has reduced the liquidity capital requirements and long-term capital requirements of enterprises, but only the demand for liquidity funds is significant. The explained variable of model (3) is the investment efficiency, that is, the test result of formula (4.1); the difference term of model (3) is no longer significant. Therefore, it can be shown that the influence of the Guidelines on corporate investment efficiency is indeed affected by the demand for funds, especially the demand for liquidity funds, with Hypothesis 2 not rejected.

\subsubsection{Impact of Financial Ecological Environment} Heterogeneity. It can come to light from Table 9 that the absolute value of the regression coefficient of the differential term with a better regional financial eco-environment is greater than the regression coefficient of the differential term with a poor regional financial eco-environment, and the regional differential term with a good financial eco-environment is significant at the level of $5 \%$. We can find a better financial ecological environment can indeed increase the impact of the Guidelines on investment efficiency, and Assumption 3 cannot be rejected. It needs to be further pointed out that the quality of the financial eco-environment can change the effect of the implementation of green credit policies; areas with a better financial eco-environment are conducive to the implementation and transmission of policies. In this study, the areas with better financial ecoenvironment include Shanghai, Beijing, Zhejiang, Guangdong, Jiangsu, Fujian, Tianjin, Shandong, Chongqing, Liaoning, and Anhui.

4.3. Robustness Test. For making the research conclusions more robust, this article first uses a placebo test and moves the policy time forward by 1 year. It is assumed that the policy is implemented in 2011 (fictitious policy), and the inspection period is set to 2007-2016. If the regression result of the difference term under the fictitious policy approach is still significant, it means that the original estimation result is likely to be biased. On the contrary, if the difference term is no longer significant, it can be explained to a certain extent that the virtual policy will not have an impact on the investment efficiency of the company, and the result of regression is robust. This article uses a placebo test to verify the impact of green credit on investment efficiency. The results show that the difference terms are no longer significant, as shown in Table 10. It can be seen that the above conclusions of this article are robust. This article also constructed a new experimental group and a control group based on the heavily polluting companies disclosed in the List of Listed Companies' Environmental Inspection Industry Classification Management as the experimental group of this article. The above process is verified again, and the result shows that the difference term is still significantly negative, as shown in Table 11. It can be seen that the classification standards of 
Table 10: Robust test (1).

\begin{tabular}{|c|c|c|c|c|c|c|c|}
\hline \multirow{2}{*}{ Variable } & \multicolumn{3}{|c|}{ Before the promulgation of the Guidelines } & \multicolumn{3}{|c|}{ After the promulgation of the Guidelines } & \multirow{2}{*}{ Difference-in-difference } \\
\hline & Experimental group & Control group & Difference & Experimental group & Control group & Difference & \\
\hline Absinvest & 0.031 & 0.025 & 0.006 & 0.025 & 0.020 & 0.005 & -0.001 \\
\hline & & & 0.001 & & & 0.001 & 0.001 \\
\hline & & & 7.8 & & & 8.53 & 0.73 \\
\hline$p>|t|$ & & & $\leq 0.001^{* * *}$ & & & $\leq 0.001^{* * *}$ & $p=0.464$ \\
\hline
\end{tabular}

Standard deviations are in parentheses; ${ }^{*},{ }^{* *}$, and ${ }^{* * *}$ indicate significant differences at $p<0.01, p<0.05$, and $p<0.001$, respectively.

TABle 11: Robust test (2).

\begin{tabular}{|c|c|c|c|c|c|c|c|}
\hline \multirow{2}{*}{ Variable } & \multicolumn{3}{|c|}{ Before the promulgation of the Guidelines } & \multicolumn{3}{|c|}{ After the promulgation of the Guidelines } & \multirow{2}{*}{ Difference-in-difference } \\
\hline & Experimental group & Control group & Difference & Experimental group & Control group & Difference & \\
\hline Absinvest & 0.032 & 0.025 & 0.007 & 0.023 & 0.020 & 0.004 & -0.003 \\
\hline & & & 0.001 & & & 0.001 & 0.001 \\
\hline$|t|$ & & & 10.24 & & & 7.38 & 3.74 \\
\hline$p>|t|$ & & & $\leq 0.001^{* * *}$ & & & $\leq 0.001^{* * *}$ & $\leq 0.001^{* * *}$ \\
\hline
\end{tabular}

Standard deviations are in parentheses; ${ }^{*},{ }^{* *}$, and ${ }^{* * *}$ indicate significant differences at $p<0.01, p<0.05$, and $p<0.001$, respectively.

heavily polluting enterprises will not affect the research hypothesis of this article, so the above conclusions still sound.

\section{Research Conclusions and Inspiration}

This article takes all listed companies in both Shanghai and Shenzhen stock exchange market from 2008 to 2017 as an object, takes the promulgation of the 2012 Green Credit Guidelines as a quasi-natural experiment, and uses the PSMDID model to empirically examine the impact of green credit policies on the investment efficiency of companies that cause heavy pollution. The conclusions are as follows: first, compared to the enterprises with minor pollution issues, the promulgation of the "Guidelines" has indeed significantly reduced the inefficient investment of heavy-polluting enterprises, thereby improving investment efficiency, and the policy effect has stabilized. Second, the promulgation of the "Guidelines" restricts the sources of funds for heavily polluting companies and improves the efficiency of companies' use of existing funds by affecting their capital needs. Third, regional policies with a better financial eco-environment are easier to implement and transmit; therefore, the promulgation of the Guidelines in these regions has a more obvious impact on the investment efficiency of heavily polluting enterprises.

The research conclusions of this paper have important guiding significance for supporting the construction of national ecological civilization and the development of green finance. The policy implications of the conclusions of this article are as follows: first, the promulgation of the green credit policy has imposed financing constraints on companies which can pollute the environment, using green to force heavily polluting companies to transform and upgrade, reduce the inefficient investment of heavily polluting companies, and improve the investment efficiency of heavily polluting companies. This also shows that the effect of the national macropolicy has been reflected in the micromarket to a certain extent. The country should further deepen the green finance policy, establish a more complete green finance evaluation mechanism, and achieve high-quality economic and social development. Second, credit financing is a booster for industrial restructuring. Green credit policy can adjust the allocation of financial resources and then affect the investment and financing decisions of heavypolluting enterprises. Financial institutions should vigorously develop green finance to help the country's supply-side structural reforms. Third, the financial eco-environment can give an impetus to the effective implementation of green credit policies. Local governments should strengthen the construction of the financial ecological environment, while promoting economic development and financial stability, they must create a good financial ecological atmosphere so that national policies can be transmitted smoothly and local enterprises can be effectively guaranteed.

\section{Data Availability}

The raw data supporting the conclusions of this article are available upon request to the author, without undue reservation, to any qualified researcher.

\section{Conflicts of Interest}

The author declares that there are no conflicts of interest.

\section{References}

[1] M. Aizawa and Y. Chaofei, "Green credit, green stimulus, green revolution? China's mobilization of banks for environmental cleanup," The Journal of Environment \& Development, vol. 19, no. 2, pp. 119-144, 2010.

[2] R. M. Naveiro and A. Aoussat, "Systematic literature review of eco-innovation models: opportunities and recommendations for future research," Journal of Cleaner Production, vol. 149, pp. 1278-1302, 2017. 
[3] S. C. Myers, "Determinants of corporate borrowing," Journal of Financial Economics, vol. 5, no. 2, pp. 147-175, 1977.

[4] M. P. Narayanan, "Managerial incentives for short-term results," The Journal of Finance, vol. 40, no. 5, p. 1469, 1985.

[5] C. Luo, Q. S. Fan, and Q. Zhang, "Investigating the influence of green credit on operational efficiency and financial performance based on hybrid econometric models," International Journal of Financial Studies, vol. 5, no. 4, p. 27, 2017.

[6] M. Lemmon and M. R. Roberts, "The response of corporate financing and investment to changes in the supply of credit," Journal of Financial and Quantitative Analysis, vol. 45, no. 3, pp. 555-587, 2010.

[7] M. Allet and M. Hudon, "Green microfinance: characteristics of microfinance institutions involved in environmental management," Journal of Business Ethics, vol. 126, no. 3, pp. 395-414, 2015.

[8] J. Sun, H. F. Wang, and B. Zhang, "Money talks: the environmental impact of China's green credit policy," Journal of Policy Analysis and Management, vol. 38, no. 3, p. 653, 2019.

[9] R. Levine, "Financial development and economic growth: views and agenda," Journal of Economic Literature, vol. 6, pp. 688-726, 1997.

[10] S. Labatt, "Environmental finance: a guide to environmental risk assessment and financial products," Transplantation, vol. 66, no. 8, pp. 405-409, 2002.

[11] P. Guo, "Financial policy innovation for social change: a case study of China's green credit policy," International Review of Sociology, vol. 24, no. 1, pp. 69-76, 2014.

[12] C. X Jing, "Financial ecological environment, ownership and debt-financing structure," Journal of Shandong University(Philosophy and Social Sciences, vol. 03, pp. 100-106, 2011.

[13] J. Y. Liu, Y. Xia, Y. Fan et al., "Assessment of a green credit policy aimed at energy-intensive industries in China based on a financial CGE model," Journal of Cleaner Production, vol. 163, p. 293, 2017.

[14] F. M. Michael, "Does the source of capital affect capital structure?" Review of Financial Studies, vol. 19, no. 1, pp. 45-79, 2005.

[15] G. Dosi, "Finance, innovation and industrial change," Journal of Economic Behavior \& Organization, vol. 13, no. 3, pp. 299-319, 1990.

[16] H. Mengze and L. Wei, "A comparative study on environment credit risk management of commercial banks in the asiapacific region," Business Strategy and the Environment, vol. 24, no. 3, pp. 159-174, 2013.

[17] M. Faulkender and R. Wang, "Corporate financial policy and the value of cash," The Journal of Finance, vol. 61, no. 4, pp. 1957-1990, 2006.

[18] G. C. Biddle and G. Hilary, "Accounting quality and firm-level capital investment," The Accounting Review, vol. 81, no. 5, pp. 963-982, 2006.

[19] M. Peeters, "Does demand and price uncertainty affect Belgian and Spanish corporate investment?. discussion papers," REL-Recherches Economiques de Louvain, 2001.

[20] R. D’Mello and M. Miranda, "Long-term debt and overinvestment agency problem," Journal of Banking \& Finance, vol. 34, no. 2, pp. 324-335, 2010.

[21] L. Yang, Evaluation of Urban Financial Ecological Environment in China, People's Publishing House, New Delhi, India, 2005.

[22] N. Bloom, S. Bond, and J. Van Reenen, "Uncertainty and investment dynamics," Review of Economic Studies, vol. 74, no. 2, pp. 391-415, 2007.
[23] S. M. Fazzari, R. G. Hubbard, and B. C. Petersen, "Financing constraints and corporate investment," Brookings Papers on Economic Activity, vol. 1, pp. 141-195, 1988.

[24] E. Wang, X. Liu, J. Wu et al., "Green credit, debt maturity, and corporate investment-evidence from China," Sustainability, vol. 11, no. 3, p. 583, 2019.

[25] R. J. Indjejikian, "Discussion of accounting information, disclosure, and the cost of capital," Journal of Accounting Research, vol. 45, no. 2, pp. 421-426, 2007.

[26] L. Li and F. Tao, "Selection of optimal environmental regulation intensity for Chinese manufacturing industry-based on the green TFP perspective," China Industrial Economics, vol. 05, pp. 70-82, 2012.

[27] D. Su and L. Lian, "Does green credit policy affect corporate financing and investment? evidence from publicly listed firms in pollution-intensive industries," Financial Research, vol. 12, pp. 123-137, 2018.

[28] S. Richardson, "Over-investment of free cash flow," Review of Accounting Studies, vol. 11, no. 2-3, pp. 159-189, 2006.

[29] AGcB, BGH, and CRSV, "How does financial reporting quality relate to investment efficiency?" Journal of Accounting and Economics, vol. 48, no. 2-3, pp. 112-131, 2009.

[30] X. Wang, F. Chen, O. K. Hope et al., "Financial reporting quality and investment efficiency of private firms in emerging markets," Social Science Electronic Publishing, vol. 86, no. 4, pp. 1255-1288, 2011.

[31] D. Xie, "Financial ecological environment, property right and governance effect of debt," Economic Research, vol. 44, no. 05, pp. 118-129, 2009.

[32] Z. Wei, "Financial ecological environment and corporate financial constraints-evidence from Chinese listed firms," Accounting Research, vol. 05, pp. 73-80, 2014.

[33] J. J. Heckman, H. Ichimura, and P. E. Todd, "Matching as an econometric evaluation estimator: evidence from evaluating a job training programme," The Review of Economic Studies, vol. 64, no. 4, pp. 605-654, 1997.

[34] Z. Fan, F. Peng, and C. Liu, "Political connections and economic growth: evidence from the DMSP/OLS satellite data," Economic Research, vol. 51, no. 1, pp. 114-126, 2016.

[35] P. R. Rosenbaum and D. B. Rubin, "Constructing a control group using multivariate matched sampling methods that incorporate the propensity score," The American Statistician, vol. 39, no. 1, pp. 33-38, 1985.

[36] X. Chang, S. Dasgupta, and G. Hilary, "The effect of auditor quality on financing decisions," The Accounting Review, vol. 84, no. 4, pp. 1085-1117, 2009.

[37] R. M. Baron and D. A. Kenny, "The moderator-mediator variable distinction in social psychological research: conceptual, strategic, and statistical considerations," Journal of Personality and Social Psychology, vol. 51, no. 6, p. 1173, 1986.

[38] D. Satterthwaite, "Environmental transformations in cities as they get larger, wealthier and better managed," The Geographical Journal, vol. 163, no. 2, pp. 216-224, 1997. 